\title{
Ambiances
}

anbiances Environnement sensible, architecture et espace urbain

\section{The Phenomenology of a Railway Expedition in China: The Gate, the Station, the Journey and the Arrival}

Junjie Xi and Paco Mejias Villatoro

\section{(2) OpenEdition}

\section{Journals}

\section{Electronic version}

URL: http://journals.openedition.org/ambiances/3074

DOI: 10.4000/ambiances.3074

ISSN: 2266-839X

\section{Publisher:}

Direction Générale des Patrimoines - DAPA - MCC, UMR 1563 - Ambiances Architectures Urbanités $(\mathrm{AAU})$

\section{Electronic reference}

Junjie Xi and Paco Mejias Villatoro, «The Phenomenology of a Railway Expedition in China: The Gate, the Station, the Journey and the Arrival », Ambiances [Online], Varia, Online since 18 May 2020, connection on 20 May 2020. URL : http://journals.openedition.org/ambiances/3074 ; DOI : https:// doi.org/10.4000/ambiances.3074

This text was automatically generated on 20 May 2020

\section{(2) $\odot \Theta \Theta$}

Ambiances is licensed under a Creative Commons Attribution-NonCommercial-NoDerivatives 4.0 International License. 


\title{
The Phenomenology of a Railway Expedition in China: The Gate, the Station, the Journey and the Arrival
}

\author{
Junjie Xi and Paco Mejias Villatoro
}

\section{Introduction}

Parallel lines across the landscape, wheels raised on steel, the power and momentum of the heavy locomotive leading its snake of carriages through a maze of switches, into and out of the tunnels, the passenger sitting a few feet above the ground, projected from the elements, hurtled from one town to the next while he reads a book or chats to friends or simply dozes, entirely freed from any responsibility for speed and steering, from any necessary engagement with the world he's passing through. Surely this is the train experience everywhere.

(Parks, 2014, p. 2)

1 This is a train travel experience described by Tim Parks in the book Italian Ways: On and off the Rails from Milan to Palermo. Is it true that all the train experiences are similar? And if not, what are the differences? What is so unique about train travel in China and how this has developed in the last decade? The train travel experience is neither a fashion nor a standard. Connected from the very beginning to modernity, train infrastructures are the positive result of industrialization and globalization as they serve people in contemporary living.

2 The railway was introduced in China by the British merchant Durand in 1864 . He built a 600-metre narrow-gauge railroad in Beijing outside the Xuanwu Gate to demonstrate the technology to the imperial court. However, it was soon demolished because the Qing government said that it "scared the dragon" and was not good for Feng Shui. After several attempts, the first railways in China were built during the late $19^{\text {th }}$ century, after extensive railway networks had already been established in Europe, North 
America, India and Japan. From the time of the First Opium War (1839-1842) to the end of the Qing Dynasty (1911), the Chinese railroad was developed relying on foreign investment, and controlled partly by the Russian and Japanese Empires.

The development of the Chinese railway system was framed by two significant political conditions: one foreign and the other one domestic. From the foreign point of view, the growth began during a very special political moment, marked by the Xinhai Revolution stating the end of China's last imperial dynasty and establishing the Republic of China. From the Revolution of 1911 to the Nationalist Party retreat to Taiwan in 1949, the main use of railway lines and railway stations was related to wars. Railway towns, as a type of settlement, began to be developed during that time. For example, Changchun in China was originally built by the Japanese as a "model town" as part of Japan's imperialist modernization, following the establishment of the puppet state of Manchukuo in 1932. David D. Buck suggests that in its first manifestation, as a railway city and the capital of the Japanese puppet state of Manchukuo, Changchun represented the inland extension of the foreign-dominated treaty-port forms that so strongly shaped modern urbanism in China. A second major railway town was designed and built from 1905 by the South Manchuria Railway, inspired by Russian railway towns such as Dalian. It was based on the rectangular system, which contrasted with the circular walled town of old Changchun, and grid patterns became the standard for Chinese railway towns. This first development of the railway infrastructure in China was mostly controlled by the colonialist empires: Russia, Germany and Japan took over the decisions about the urban layout and the image provided by the trains' infrastructures and stations (Chen, 2013).

From the domestic point of view, the development was framed in a contradictory ideological push of modernity. From the point at which the People's Republic of China was founded (1949), a wholly new symbology was necessary for the representation of the new ideology on all scales, from a "spatial revolution" to an infrastructural one (Zhu, 2009, p. 75). As Jianfei Zhu explains, this new era was initially commanded by architects and planners who studied abroad, particularly in the United States, and who, once back in China, were required to study Mao's writings and examine the Soviet Russian examples as a way to "reform their 'bourgeois' thinking". Under pressure from the Communist Party of China and its "proletarian dictatorship", Chinese architects were involved in the definition of the new China, but they lacked the necessary autonomy to achieve the "critical practice" tied to modernism (ibid., p. 104).

Within this frame, two events - the Great Leap Forward (1958-1961) and the Cultural Revolution (1966-1976) - are often considered as representing restrictions to China's modernization. Both events happened in a highly politicized and radicalized society, which expressly dismissed professional expertise, considering it counter-revolutionary, a fact that resulted in a shortage of the specialists and professional talents necessary to achieve modernity. In the process of modernization, train stations, as buildings, symbolized technological progress and economic power. Elisabeth Köll argues in her book Railroads and the Transformation of China that, as an important part of China's economic and social reconstruction, railroads did not escape the reach of the mass political campaigns of the late 1950s and 1960s. Providing services to achieve the economic and political goals of the Great Leap Forward and the Cultural Revolution, railroads "simultaneously became both agents and victims of these destructive campaigns" (Köll, 2019, p. 254). 
During the Great Leap Forward, the mobility between urban and rural environments, which mostly happened through the railway network, was strictly invigilated to control the movement of the population and goods between both environments. In the Cultural Revolution, technical inefficiencies and economic mismanagements were common in an infrastructure politically devoted to spreading Mao's message across the country and overwhelmed by a crowd of teenage Red Guards. In both cases, the railway infrastructure was dismissed as a tool for technical progress - in a closer understanding of modernity's rational principles - and became a political instrument. This controversy between the political and technological capacities of the railway infrastructure lasted until Chairman Mao's death in 1976. Then, as Köll explains, Deng Xiaoping "immediately recognised the importance of a well-functioning rail sector for economic growth" (ibid., p. 256).

Recorded by Xiong Wang in his book China Speed: Development of China's High-speed Rail, on 26 October 1978, sitting on the flying high-speed bullet train, the new Chinese mandatary, Deng Xiaoping, was serene and calm. Mountains, lakes, villages and fields were flashing by on both sides of the train. Inside the compartment, the screen read: $210 \mathrm{~km} / \mathrm{hr}$. One reporter among Deng's entourage asked him, "As far as we know, sir, this is your first high-speed train ride. How do you like it?" Deng answered readily, "Fast, it runs like the wind, and it feels like pushing you to run; we're sitting on the right train." (Wang, 2016, p. 2). Two months later, the $3^{\text {rd }}$ Plenary Session of the $11^{\text {th }}$ Central Committee of the Communist Party of China was held in Beijing and marked the beginning of China's reform. Deng Xiaoping understood the impossibility of positioning China in the world of the future without accomplishing the technical development that is connected to modernity. It was at that moment when official discussions began in order to develop a high-speed train network in China. The fact that it took more than 20 years to start operational lines is not surprising if the aforementioned historical background is considered. With the politically centred failed approaches to modernity represented by the Great Leap Forward and the Cultural Revolution, China, under its new leadership, recognized the necessity of providing a more technical and economical approach. This was the beginning of a re-emergence of "modernity", as suggested by Thoralf Klein, as a master narrative that took place in the 1990s (ibid.).

8 The year that Beijing hosted the 2008 Summer Olympics marked 30 years of China's reform. One year before, China had begun a new generation of passenger-dedicated high-speed railway (HSR) services, and since then over 300 stations have been built or renovated to accommodate high-speed trains. By the end of 2019, in just a few years, China had over $35,000 \mathrm{~km}$ of HSR lines - more than the addition of all the other highspeed train networks in the rest of the world and representing $70 \%$ of the total global network (Aldama, 2020).

9 In order to explore the Chinese approach to modernization, the phenomenology of the experience of a journey on board a high-speed train can be analysed. As Ariane Mildenberg states, phenomenology and modernity are interlaced (Mildenberg, 2017, p. 2). Both are based on a "primordial faith" in the interrogation of the perceptual (in phenomenology) or historical (in modernity) experiences that encourage openness. The idea of a "pre-theoretical" situation, as an experience built through only the relationship with things and facts, is shared by modernity's dismissal of history and by the phenomenological approach to experience (ibid., p. 5-6). 
10 The authors will now explore the experience of the journey through four different stages: the gate, the station, the journey and the arrival.

\section{Methodology}

11 The authors applied phenomenology as a methodological approach through four stages of a railway journey: the gate, the station, the journey and the arrival. From 2016 to 2019, with the substantial support from a research grant awarded by Xi'an JiaotongLiverpool University, the authors visited 50 railway stations across China, following different railway routes. The information about the trips is listed in the table below with repeated journeys excluded.

Table 1: The railway journeys conducted by the authors from 2016-2019

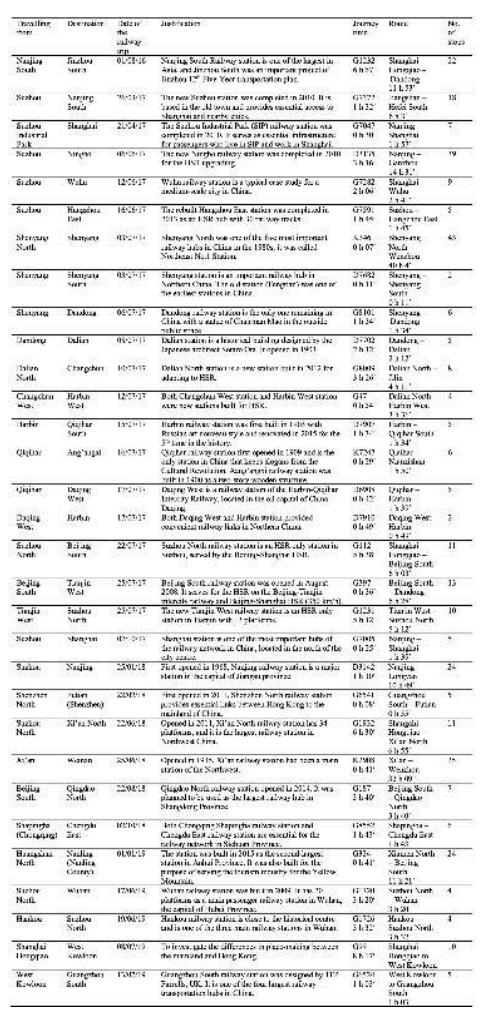


Table 2: Other stations visited without entering the platforms

\begin{tabular}{lcl}
\hline Other stations visited without entering the platforms \\
\hline Yixian station & $17 / 07 / 16$ & $\begin{array}{l}\text { A historical station opened in 1921. It provided links on the Xinyi railway line } \\
\text { built by the Imperial Japanese Army between 1935-1937. }\end{array}$ \\
\hline Beijing station & $23 / 07 / 17$ & $\begin{array}{l}\text { Designed by renowned architect Yang Tingbao to commemorate the 10 } \\
\text { anniversary of the founding of the People's Republic of China in 1958. The } \\
\text { station opened in 1959 and was the largest train station in China at the time. }\end{array}$ \\
\hline Tianjin station & $25 / 07 / 17$ & $\begin{array}{l}\text { Rebuilt in 1987 as a principal station in Tianjin. The title of the station was } \\
\text { written by Deng Xiaoping. The station serves for HSR since 2008. }\end{array}$ \\
\hline Dunhuang station & $28 / 08 / 17$ & $\begin{array}{l}\text { Dunhuang was a major stop on the ancient Silk Road and has been best known } \\
\text { for the nearby Mogao Caves. Opened in 2008, the station provided convenient } \\
\text { transportation services for both local residents and tourists. }\end{array}$ \\
\hline Jinan station & $22 / 08 / 18$ & $\begin{array}{l}\text { The current Jinan railway station was built in 1992. It is part of two lines: the } \\
\text { Beijing-Shanghai Railway line and the Qingdao-Jinan Passenger Railway line. }\end{array}$ \\
\hline Jinan West station & $22 / 08 / 18$ & $\begin{array}{l}\text { Located 20 kilometres to the west of the city centre, Jinan West railway station } \\
\text { opened in 2011. It is an HSR only station. }\end{array}$ \\
\hline Qingdao station & $23 / 08 / 18$ & $\begin{array}{l}\text { Qingdao railway station was first built in 1899 and reconstructed in 1994. It } \\
\text { had become an iconic building, and it represents part of the modern history of } \\
\text { Qingdao. }\end{array}$ \\
\hline Hailar station & $\begin{array}{l}\text { Hailar railway station was first built in 1901 on the line of the Chinese Eastern } \\
\text { Railway by Imperial Russia. Hailar is an urban district in Hulunbuir, Inner } \\
\text { Mongolia, China. }\end{array}$ \\
\hline Manzhouli station & $27 / 08 / 18$ \\
\hline Beijing West station & $\begin{array}{l}\text { Manzhouli railway station is the gateway from China to Russia. It is in } \\
\text { Manzhouli, Hulunbuir, Inner Mongolia. }\end{array}$ \\
\hline $\begin{array}{l}\text { Beijing West station opened in 1996 and it was once the largest railway station } \\
\text { in Asia. The design was controversial and provoked discussion in Chinese } \\
\text { modernism. }\end{array}$
\end{tabular}

During the research excursions, the authors observed and recorded the contemporary railway experiences, making comparisons with the Western context and possible connections between both experiences and their particular approaches to modernity. The map below shows the research trips conducted by the authors through the railway network in China. 
Illustration 1: Caption: Map of the high-speed railway network in China 2019 with the routes travelled by the authors highlighted

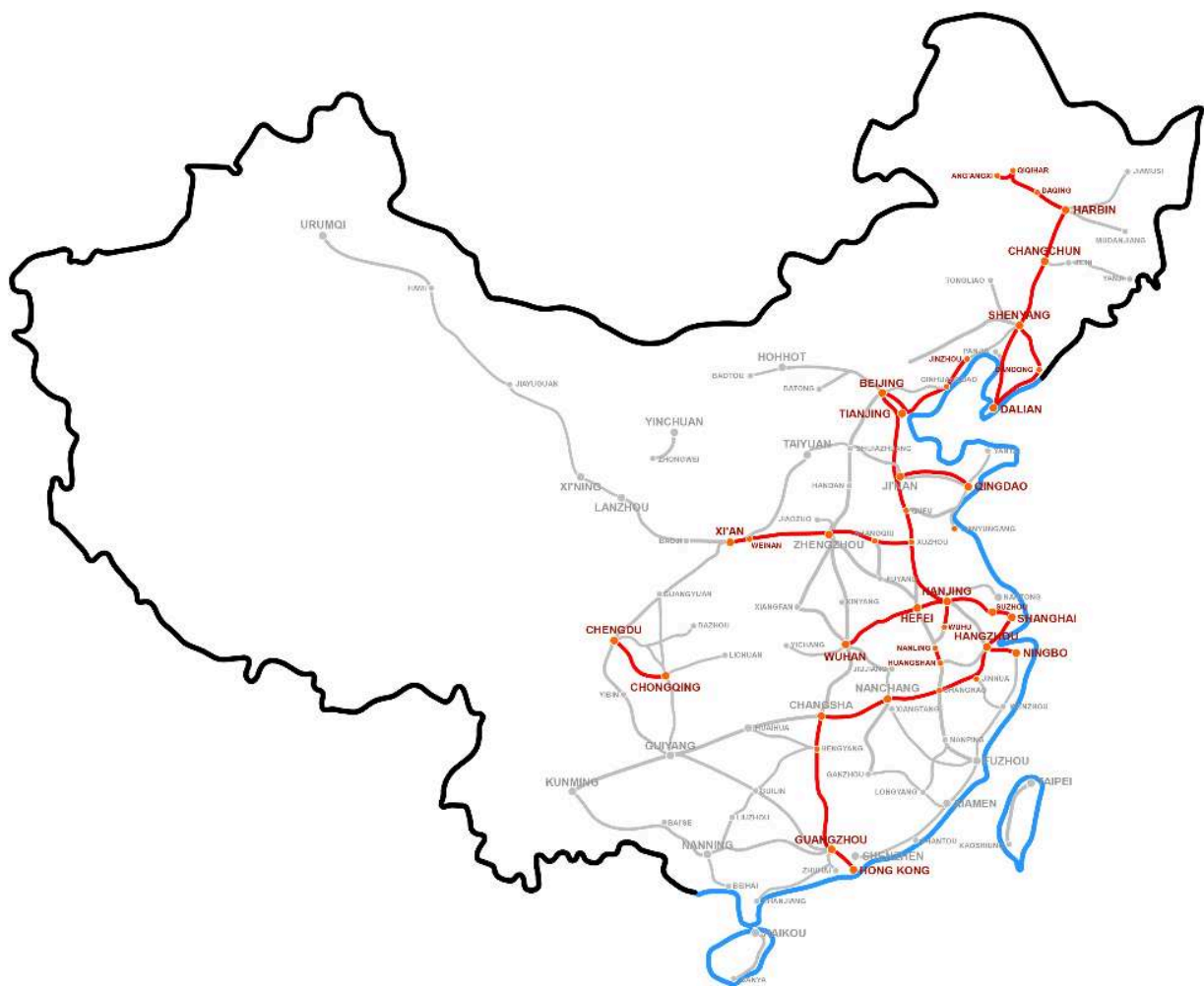

The thickness of the lines corresponds to the speed of the route (from thicker to thinner: $\geq 300 \mathrm{~km} / \mathrm{h}$, $\geq 250 \mathrm{~km} / \mathrm{h}, \geq 200 \mathrm{~km} / \mathrm{h}$, respectively)

Source: Jian, Zhen (Ed), 2019. A study of the 13th Five-Year Plan for the development and planning of railway road. Beijing: China Railway Publishing House

Copyright: the authors

\section{The Gate: Confinement and Monumentality}

Functionally, train stations are buildings in between two worlds: the engineered infrastructure and the architecture of the city. As Wolfgang Schivelbusch explains, the station functions as a kind of gateway, which has to connect two very different types of traffic and spaces with one another: the traffic space of the city and that of the railroad. One element of the station, the neoclassical stone buildings, belongs to the city; the other part, the steel and glass construct, is a pure function of the railroad's "industrial" side (Schivelbusch, 1977, p. 162). This difference is an essential part of the experience of leaving: a dissolution of the materiality of the city, which goes from the particularities of the urban context that are left behind to the anonymity of the rail tracks that lie ahead.

The experience mentioned above is easily recognized as part of the Western context, where train infrastructures were generated during an essential stage of the reconfiguration of the cities, hence becoming an integrated part of the urban extensions and refurbishments during the mid- $19^{\text {th }}$ century (following the examples of London and Paris). Even when, later on, some Western cities fronted the reconfiguration of stations in order to adapt them to the new conditions of the HSR, 
this was mostly completed with an attempt to retain the proximity between the old and new facilities or, at least, between the new facilities and the main core of the city.

When referring to the chinese context, the situation changes: mostly located in suburban or even ex-urban contexts (Chen, Wei, 2013), often not well connected by public transportation, and surrounded by unproportioned public spaces, the new highspeed railway stations provide a different experience. Technical, financial and strategic factors have been argued as explaining this fact, and all of these have, in some way, a connection with the understanding of Chinese modernization.

The stations are dispersed due to technical difficulties in accommodating the alignments of the high-speed track and its demands for high-radius curves within a city planned in the context of the Cultural Revolution (Haixiao, Ya, 2019, p. 61). During that time, following Mao's anti-urban and anti-professional push, most of the planning was commanded by the working class, resulting in uncoordinated and misguided decisions regarding the development of future infrastructures (Qian, 2014). With an emphasis on the industrial enhancement of cities, most of the infrastructural layouts completed during that time were focused on connecting industries and moving goods rather than providing transportation for people.

It is also clear that suburban and ex-urban locations are cheaper in terms of the necessary compensation and relocation of people, with the rural population being a more docile one in terms of accepting drastic top-down initiatives. Most of the new peripheral stations have been built on small outlying villages or their associated farmlands. They have been planned with the idea of provoking further development to increase the value of the land and, in doing so, alleviating the payback of the infrastructure investment. Most of these plans have not been very successful in attracting investors and developers; for instance, the Wuhan railway station master plan, created in 2007, is now clearly underdeveloped, a fact that is very significant within the context of the usual Chinese fast pace or urban transformation (Illustration 2).

\section{Illustration 2: Left, the vision of the Wuhan station master plan and right, the "urban axis" still} waiting to be developed in 2019
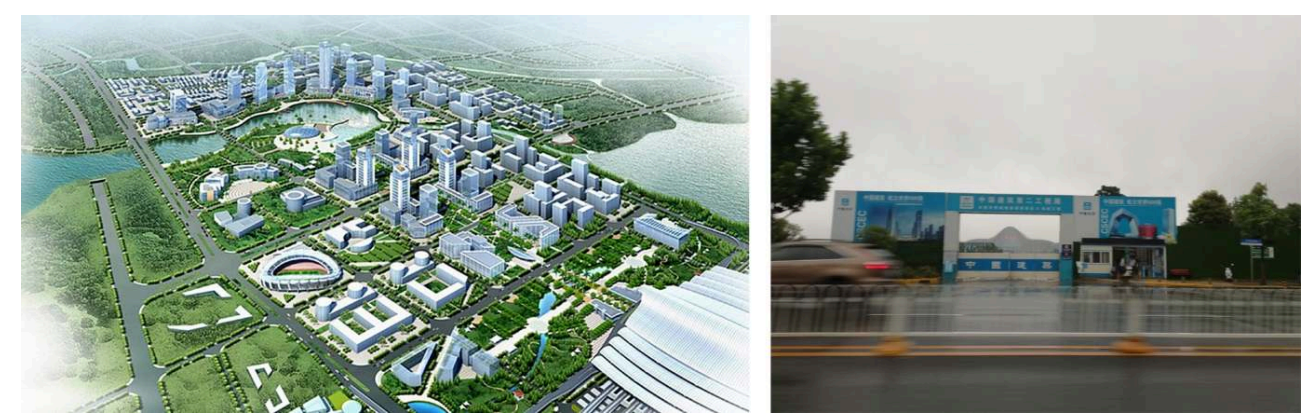

Source left: Comprehensive Plan for Wuhan Yangchun-lake Sub-centre, 2007 (from the official website of Wuhan Land Resource and Planning Bureau: http://www.wpl.gov.cn

Copyright left: Wuhan Land Resource and Planning Bureau Source and Copyright right: the authors

The peripheral situation of the stations has also been explained as part of a wider urban strategy based on a model of urban transformation: from the centric to the polycentric city. This strategy is difficult to trust if, as Pan Haixiao and Gao Ya suggest, the decision is not accompanied by proper planning of the connection between the different cores, 
which, in the case of China, is highly flawed in most cases (Haixiao, Ya, 2019, p. 61). For instance, $38 \%$ of the people arriving at the stations on the Beijing-Shanghai line arrived by taxi, as a demonstration of the lack of a coordinated effort between intercity and local mobility (ibid., p. 68).

Without entering a broad discussion about modernity (from the urban exaltation of Baudelaire to the political reading of Foucault, or from those who consider multiple modernities, such as Eisenstadt, to those such, as Latour, who denies its existence), what is undeniable is that the situation described has a connection with the particularity of the Chinese modernity or with its process of modernization. The common components mentioned as substantial elements relating to this "modernity" are the emergence of industrial capitalism and the derived process of urbanization; the intensification of global communication; and the spread of scientific rationality (Klein, 2014, p. 278). However, these concepts are conditioned by a capitalist plot that cannot be directly linked to the Chinese case. As Klein points out, instead of trying to fit China into an official (and Western) narrative of modernity, it would seem more interesting to be able to delineate its particularities, with the "tensions within modernity" being one of the most intriguing ones (p. 280). The tensions between different spatial-social entities (such as city and countryside) and between a singular and plural reading of modernity are the most useful for understanding the Chinese process of modernization. These pressures were at the base of problems such as the Great Famine (the greatest human-made disaster in history), when urban collectives deprived individuals from the countryside of decisions about their own agricultural production, forcing an impulse of modernity by bringing rationalization and bureaucratic planning (p. 288). The same tensions can still be recognized through the dismissal of rural environments and the conflict between public and private interest in the questionable decisions relating to the placement of HSR stations, as discussed before.

The initial confrontation between urban and rural populations created by the Great Leap Forward has lasted until present times. As Klein reminds us, Chinese peasants are even today considered "second-class citizens", with the semantics of the word "peasant", as they are referred to by the Chinese, connected with pre-modern terms as "feudalism" and "superstition". This condition accompanies the peasants even when they move to the urban, transforming the Chinese urban context into a place with uneven modernity (Ibid., p. 286-287).

Once at the station, it is easy to recognize the gate as an entry. The gate has always had an important symbolic meaning in the history of China. Segregated by administrative divisions and subdivisions, the ancient Chinese city was characterized by a continuous transition through gates (paifang). Even now, an isolated paifang has become the most characteristic representation of a Chinese neighbourhood in Western cities. Without pointing out the historical importance of seclusion and the gate as the transition between parts, it is difficult to understand the idea of a city where parts are more formally independent, as happens, for instance, through the remote location of the HSR stations mentioned before or through the proliferation of gated communities in China.

As stated earlier, the transition to the stations - the initial point of departure - in the Western context is smooth and integrated within the existing city, a fact that could be related to a fundamental difference in the significance of the journey. Travelling in compact Europe cannot be compared with travelling in the huge territory of China, where displacements sometimes supposed an all-live-time separation. In the poem "A 
Song in the Name of the Town of Wei", written by Wang Wei from the Tang Dynasty $\left(7^{\text {th }}\right.$ to $10^{\text {th }}$ century $\mathrm{AD}$ ), he described his emotions when he was sending his friend to the west of China. In the poem, he expressed a contradictory feeling of melancholy tinted by excitement for the future represented by a new beginning. These antonymous emotions capture the beginning of the journey perfectly.

A morning drizzle in the Town of Wei light dust on the ground wets, outside the hostel willows, grow green and fresh.

Bidding you farewell, I'd like to offer you one more toast, for west of the Sun Gate you won't come across any old friend.

The perception of an overwhelming monumentality commonly characterizes the approach to the entry to a new HSR station in China. There are a few features of monuments (as stated by Giedion, Sert and Leger in their Nine Points on Monumentality, 1943) that can be easily recognized in the new Chinese railway stations: more than just strictly functional buildings, they are landmarks that express a unified consciousness of mighty economy. In a more contemporary reflection, in 2008 Larry Ford identified four dimensions of monumentality, namely: legibility, iconicity, integration with a major transportation hub, and a plan for developing a significant part of the existing city (Ford, 2008). Even though two of these characteristics (legibility and iconicity) have some degree of subjectivity (as stated by C. J. Smith, 2008), all four are to some degree recognizable in most of the new high-speed train stations in China. For a better understanding of the peculiarities of monumentality, Smith refers to two explicit questions about the decision-making process involved in these projects, both of which need to be reframed in the specificities of the Chinese political context: the first discusses the level of authoritarianism involved and the second debates the level of people's acceptance when the project has been completed (ibid., p. 265). As Smith reminds us, in authoritarian places, where very few people are involved in the decisions affecting the city planning and where little attention is paid to users' opinions, there is a crucial difference in the understanding of monumentality. Under the Chinese "red capitalism" (as Lin has referred to it), the State provides the fast and effective mobilization of the other agents and processes involved, from providing the land to encouraging developers and local governments, and facilitating the workforce through changing the restrictions on rural to urban migration (Lin, 1997). This top-down condition is balanced by a more bottom-up element (always on a governmental level) consisting of fierce competition between municipalities that use their progressively higher autonomy in decision-making for pushing their local economies and for promoting their local representatives to a national level.

Within this background, what can be perceived during the approach to the new Chinese high-speed train stations is a monumentality formally based on disproportionate public spaces and simple imagery. Scale and symmetry in monumental architecture are embraced by archaeologists as the primary vocabulary in past statements of power. The public space seems to act to underline the presence of the monumental station, with a total disregard for the pedestrian experience, resulting in unpleasant spaces to be in and even to cross. Unlike similar monumentalism in the European context, in the case of China, the unwelcoming effect of these spaces is magnified in most cases by the nonurban location of the new HSR stations. It is in the grandness of these spaces where the station is placed, axially and symmetrically, creating an indissoluble connection between both and containing unmistakable messages about economic and political power. 

some of the Chinese imperial architecture, in an exaggerated claim of identity after the colonialist era. For example, the now-destroyed E-Pang Palace - built in $212 \mathrm{BC}$ in the western suburbs of today's Xi'an, Shaanxi Province - covered a surface of 450 hectares, representing a monumental work that needed the commitment of over 700,000 workers. Another famous example is the Forbidden City Palace (constructed from 1406 to 1420), consisting of 980 buildings and covering 72 hectares. The public space that frames the Palace - Tiananmen Square - was enlarged in 1958, following the visionary concept of Chairman Mao. As reported by Adrian Hornsby, Mao initially stipulated that the square should be "big enough for one billion people, i.e. every single person in China [550 million at that time] plus a friend each from overseas" (Hornsby, 2009). The square is not only huge, with more than 20 hectares of purely pedestrian space, but also appears as strangely empty nowadays. At some points in time, Tiananmen Square fulfilled its practical duty, frequently hosting crowds numbering hundreds of thousands, and at its peak, in the first months of the Cultural Revolution, 11 million people congregated there over seven rallies. After the riots in 1989 (known as the "June Fourth Incident"), this space lost its original meaning and became a tightly controlled monumental void.

The public spaces around the new HSR stations are generally characterized by a similar empty monumentality. With common dimensions above five hectares (almost nine hectares in the two squares in Shijiazhuang, six hectares in Dunhuang and just over five hectares in Dalian), the spaces have been planned as isolated islands poorly connected to the surrounding city, and more as visual frames for the stations than as spaces for people (Illustration 3). In the blank canvas of these public spaces, the stations state a clear image all around, through upscaled buildings and imagery referring to distinct Chinese features or to stereotypical modernity.

Illustration 3: The square outside the Tianjin West railway station (left), 2017; the south square of Suzhou railway station, 2016 (right)
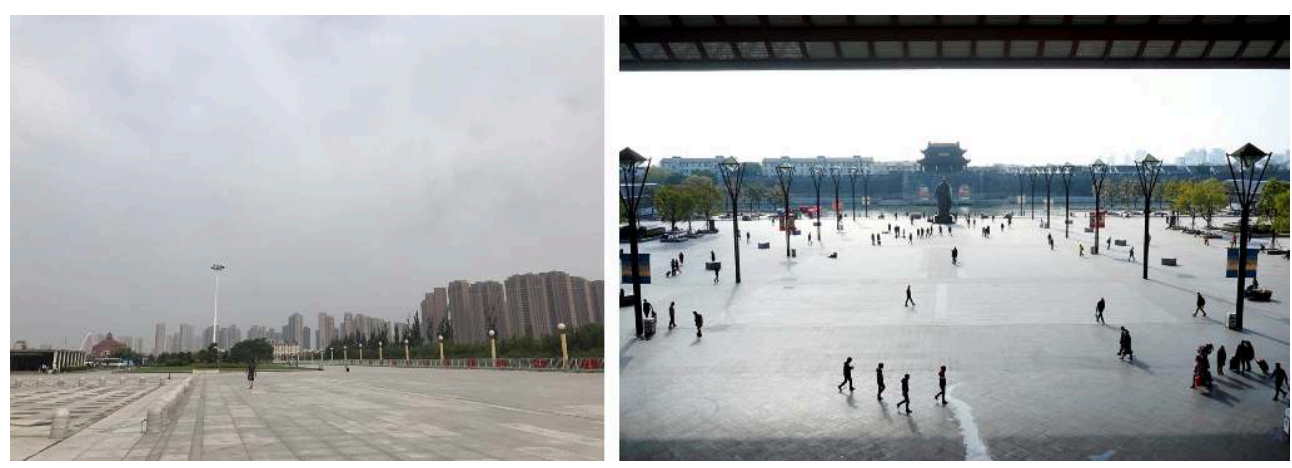

Source and Copyright: the authors

The Beijing West railway station (completed in 1996 and designed as the west gate of Beijing - shown in Illustration 4, left) boldly refers to China's architectural heritage by imposing a series of traditional Chinese pavilions on the top of a monumentally scaled modern station. In this and other respects, the project shares certain affinities with Yang Tingbao's Beijing railway station (Illustration 4, right), one of the ten major projects of 1959. However, the new project is larger in scale and incorporates more imagery of Chinese architectural features. As in Yang's earlier station, the concourse 
and the bulk are modern, both in planning and in the expression of materials and building structure; the traditional iconographic elements are concentrated primarily near the centre of the very extensive, 740-metre-long northern facade, in a prominent display of architectural symbolism (Rowe, Kuan, 2002, p. 182).

Illustration 4: Beijing West station (left); Beijing railway station (right)
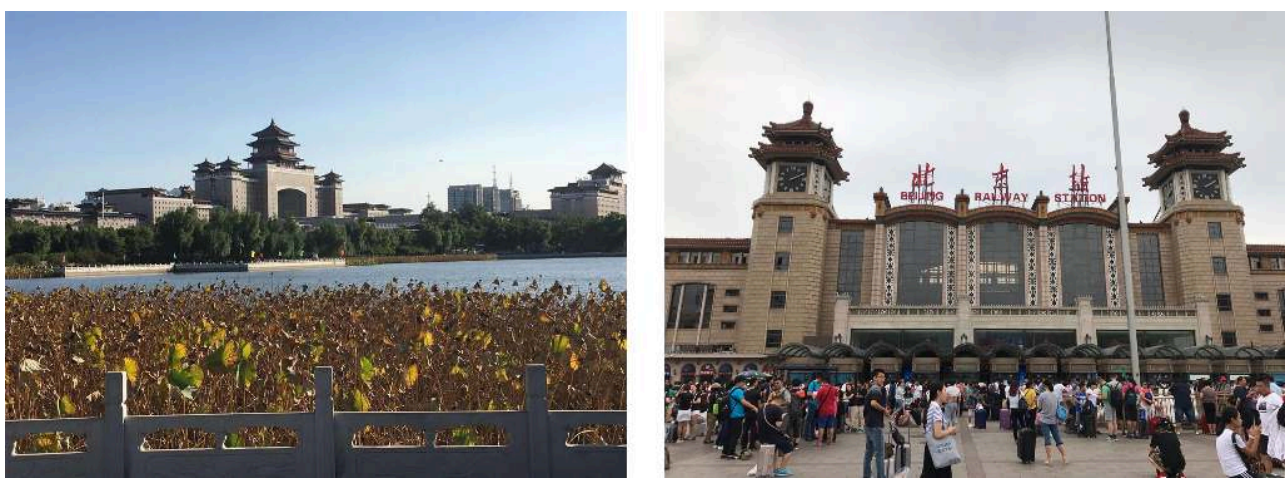

Source and Copyright: the authors

Another more contemporary example is Dunhuang station (Illustration 5, left). The city of Dunhuang was a main stop on the ancient Silk Road and is best known for the Mogao Caves nearby. The railway station was built not long ago, in 2006, as the second-largest railway station in Gansu Province. Although the high-speed railway is not available yet, due to the city's topography, the station already brings many benefits for the tourists visiting from nearby areas. The design of the station captures features of Dunhuang's culture in the form of an ancient gate, including the saddle roof.

In some cases, the monumentality of the station is presented through sculptures rather than through the building itself - for example, the Dandong station in Liaoning Province, which is the gateway from China to North Korea (Illustration 5, right). Passengers can reach Pyongyang by train from Dandong within six hours. As a gateway, the station currently in use was completed in 2009, following a second reconstruction. Apart from all the signs being in both Mandarin and Korean, the station has few features of the local architecture. However, the station is the only one in China to retain a statue of Chairman Mao, which was erected in 1971 during the Cultural Revolution.

Illustration 5: Dunhuang railway station (left); Dandong railway station, 2017 (right)
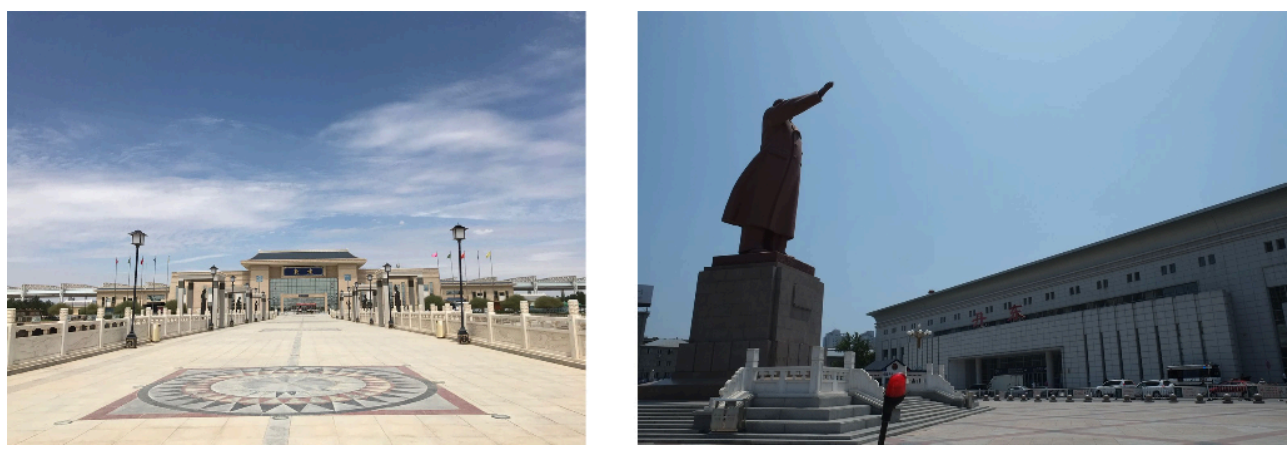

Source and Copyright: the authors 
Parallel to this series of stations devoted to the re-creation of Chinese symbolic features, there is another type that seems to point to a new, more contemporary image. Mostly projected through the different design institutes, stations such as Daqing West (Illustration 6, right), Shenyang South (Illustration 6, left) and Wuhu are aligned with what we could call a populist modernism, characterized by facades that retain symmetrical layouts, displaying a superficial lattice of horizontal lines, perhaps referring metaphorically to the speed of the train or allegorically to the rail tracks.

Illustration 6: Shenyang South railway station (left); Daqing West railway station (right)
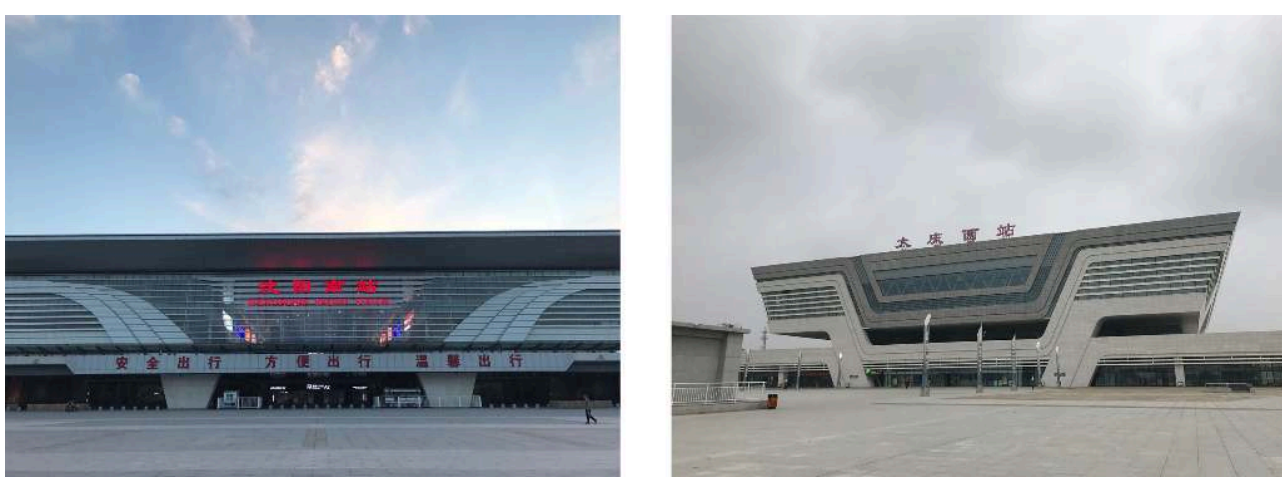

Source and Copyright: the authors

In addition to this experiential approach - from the individual's point of view - it is important to point here to the political significance of the stations. As Michel Foucault notes, the architecture promoted by the State has always had a mission going beyond just the configuration of space, which is to "permit an internal, articulated and detailed control" (1991, p. 172). If, as he reminds us, the hospital is an instrument of medical action and the school is a mechanism of training, it can be argued that the train stations in China are a mechanism of social docility (Ibid.) through their intimidating monumentality and their restricted access.

Even though in our post "nine-eleven" era, controlled access to strategic infrastructures is a common feature all over the world, this occurs in China in a very different manner than it does in the Western context. In the West, security controls take place with a level of discretion that aims to dissipate the unwelcoming effect of it, smoothing the transition from the free and open space of the city to the controlled space of the station. Identity checks rarely happen in Western stations and the security checks take place further in on our way to the platforms (sometimes on the platforms themselves), rendering the station's main halls an extension of the open space of the city.

In contrast, the experience of entering a Chinese railway station is commonly characterized by an intense feeling of restriction. Handrails are everywhere, and a programmed method of directing the flow of people takes over the experience of the entrance, overflowing from the doors and occupying the outside public space, which has become partially restricted too. Under the argument of public safety - the same argument that supports the massive presence of surveillance cameras in the public space - the experience of approaching train stations is homogenized through selected paths and perspectives that are far from simply casual decisions. Passengers need to go through a security area before entering the station, and tickets need to be checked at 
the same time as passengers' identity cards. China deployed a real-name ticket sale system from 2010, as a way of trying to stop ticket scalping and improving railway security, with "security", as mentioned before, a code-word for control. Foreign travellers can only collect their tickets from the ticket office in the train station with their passports, which is often described as inconvenient for frequent travellers. The physical confinement in the station's entrance is, in this way, completed by wider confinement in the city, based on the official recording of your movements and on the necessity of the authorities' approval for departing. The restriction of the right to move is then a consequence of the restriction of the right to stay, which in China is controlled through the necessity of holding a registration certificate (hukou) for being a resident in any place. All these restrictions are principles that challenge the defence of individual freedom embedded in the ideology of modernity - obstructions that are paradoxically overlapped with the impressive display of technological modernity.

All these unfamiliarities frame the experience of the departure in accordance with Marcel Proust's statement that the beginning of the rail journey implies the end of our familiar routines and the beginning of the strangeness of the world (1981, p. 694).

\section{Inside the Station}

The monumental perception of the outside of the train stations is usually continued in the interior. Generally, based on a big-hall scheme, the spaces could be extremely crowded or surprisingly empty, depending on the time of year (Illustration 7). During the Chunyun or spring festival - the largest annual human migration in the world around 3 billion displacements happen during a period of 40 days (2019 data reported by The South China Morning Post). This massive migration is mostly undertaken by train, provoking the collapse of train stations across China. The necessity of accommodating this peak moment would explain the oversized interior spaces at the stations. Statistics show that trains are the most-used intercity method of transport in China. According to the 2017 China Statistical Yearbook, the passenger volume of railway transport during that year exceeded 2.8 billion, which is 3.7 times the combined total of passengers who travelled by water and civil aviation transport (Huan, 2018).

Illustration 7: A crowded Hankou railway station, 2019 (left); empty steps of Changchun West railway station, 2017 (right)
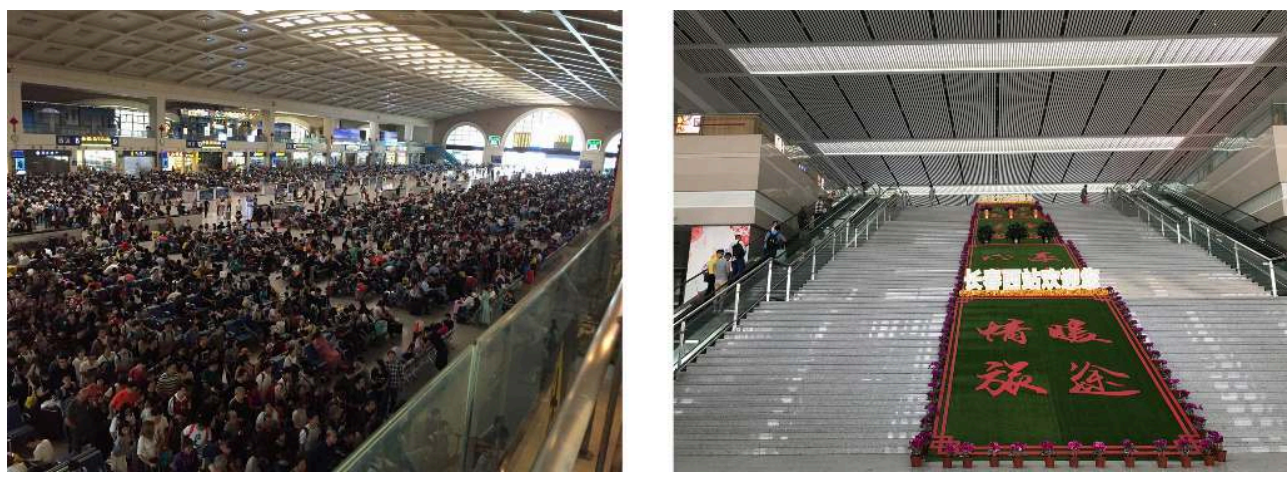

Source and Copyright: the authors

Once seated in the waiting hall, the limits of the space become lost in between the crowds or diffused by the huge distances, provoking the dissolution of the architectural 
space. Open daily to the waiting areas, there are shops and restaurants. Toilets are often arranged on the two sides of the station, facing the waiting areas and widely open. The smell of urine keeps passengers away from these areas, an odour that gradually transforms into pot noodles and other Chinese food as passengers progress along the hall. The sound of the speakers echoes in the space, while the lights are reflected in the shiny floors that are so characteristic of Chinese public buildings, contributing too in this way to the dematerialization of the space. Due to their vast dimensions, these main halls are not well air-conditioned, with sometimes no difference between the outdoor temperature and the interior one, reinforcing an open-space feeling. The limited ventilation makes it almost unbearably hot in summer when some of the stations need to display ice containers in a desperate attempt to cool down the space (see Illustration 8, left, showing summer in Suzhou station). The monochromatic materiality of the space (usually pale grey or white) lightens the interior, underlining the colour of the people and the screens, which becomes the primary reference in a repetitive space with no or very few visual connections with the exterior (Hangzhou East station's hall in Illustration 8, right).

From a phenomenological point of view, it is essential to include here a reflection about time, connecting the perception of the waiting space and the idea of subjective time. As Husserl points out, it is subjective time or time-consciousness, that is the phenomenological datum that provides a temporal character to "objects of perception, memory and expectation" (Husserl, Brough, 2011). There is an interesting connection between the present, past and future perceptions of time (the Husserlian "thickness" of time, as named by Dostal) and the way in which time is perceived in connection with concepts of memory (past) and expectations (future) - or, as Husserl defines them, the retentive and protentive conditions of time, respectively (Dostal, 2006).

Memory and expectations are essential components of the phenomenology of the journey that is deployed in the waiting space of the station. During waiting time, passengers are continuously referring to events that are expected to happen in the future, in connection with memories of what has happened in similar situations, in this way keeping expectations and memory in permanent and close relation. The routine of the train schedules, which represents a reference to the consolidated past, is supported by the will to cover the passengers' expectations about the journey, all reflected in the light of the information screens. Memory and expectations are two concepts that are also connected to the idea of modernity. The dismissal of memory and an overestimation of expectancies for the future are two common characteristics found in the diversity of the modernity theory.

The denial of history has happened in a similar way in the East and the West, with different origins and consequences. In the West, modernity was induced in society as a consequence of the technical evolution deployed since the Industrial Revolution: technological progress changed living conditions and the built environment in a way that made people feel optimistic about a more exciting future world. In the East, more specifically in China, the technological progress was a top-down mandate that had terrible consequences for the population in a technologically underdeveloped society. The Great Famine marked a whole generation that acknowledged these dramatic facts as part of the failure of modernity. If the dismissal of memory was based on technological optimism in the West, in China there was a political demand grounded in 
the denial of the old regime, but in both cases, the perception of time lost the aforementioned "thickness" with the exclusion of its past side, the side of the memory.

It is important to also mention at this point that Western and Eastern ideas of time are conceptually very different. As Klein points out, the more Western linear understanding of time was not fully alien to the East (which, for instance, records genealogy in a linear way), but in China the most predominant historiographic reading was cyclical (2014, p.289-290). The change in this mode of time perception in China is also connected to the particularities of its modernity, affected by "the confrontation with imperialism and the experience of dynastic decline" that shunted the chinese time perception to a more linear, or Western, understanding, formalized through the adoption of the Gregorian calendar as one of the first measures of the Republican government in 1912 (p. 290).

Illustration 8: Children playing with ice blocks inside Suzhou station, 2018 (left); the interior of Hangzhou East railway station (right)
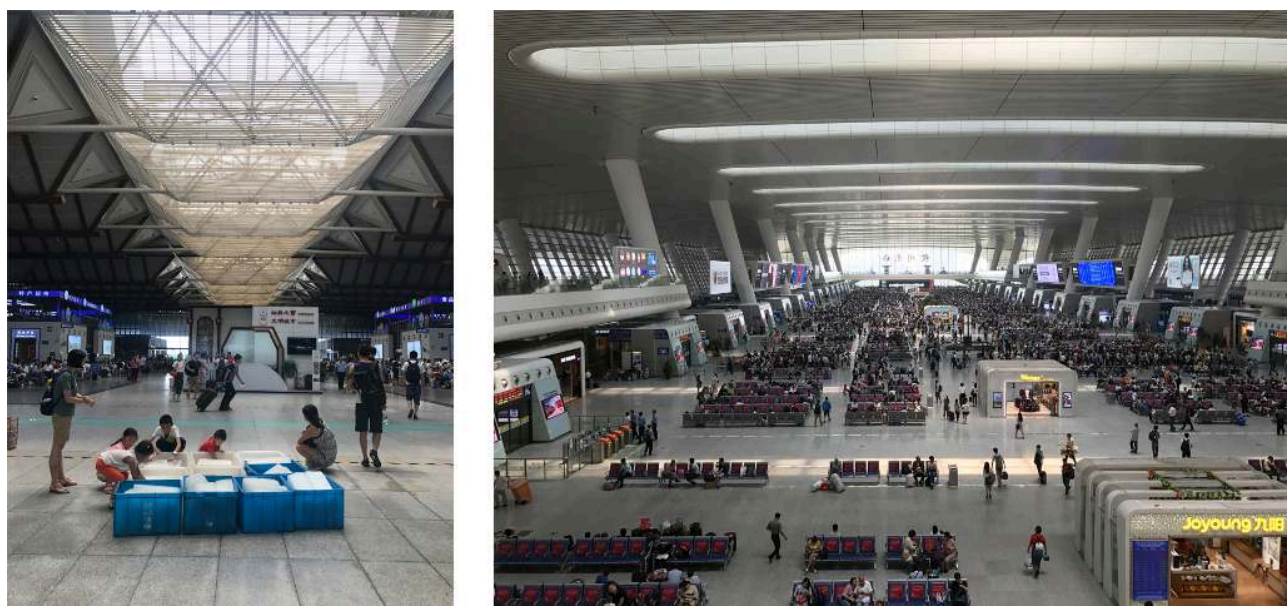

Source and Copyright: the authors

The transition to the platforms is preceded by an automatic checking process and the subsequent human queue. On their way out, desperate smokers start to light their cigarettes, and the arrival at the platforms is shrouded by the combined smell of humans and tobacco, just at the moment when the futuristic beauty of the high-speed trains appears in front of our eyes. With the change of the vast hall space to the linear space of the platforms, time perception also shifts from the thick waiting time to a lighter one where expectancies take over, in a fully protentive experience. The passengers are ready to depart. 
Illustration 9: Fuxing Hao ready for departure (left); a man smoking at the platform of Xi'an station (right)
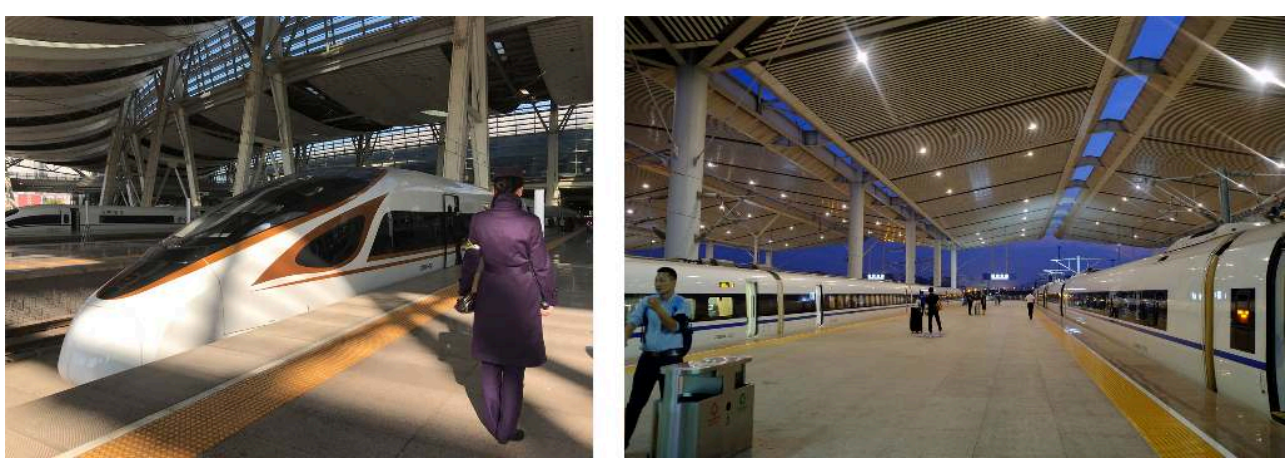

Source and Copyright: the authors

\section{The Journey}

Nicholas Daly argues that the railway must be understood as more than a simple mode of transport: for the Victorians, it stood as both agent and icon of the acceleration of the pace of everyday life; it annihilated an older experience of time and space and made new demands on the sensorium of the traveller (Daly, 1999). Since the 1950s, scholars have been exploring the way in which the perception and body sensations change when people experience the environment from a moving vehicle. As Gibson points out, perception in movement produces a blurry foreground and an outline of the background, both effects that are especially important in a transportation mode, where "visual stimulation becomes proportionally more important than the bodily stimulation" (Gibson, 1977, p. 135). In such a rapid movement as that produced by the high-speed train, prehension - as the anticipation of the body's sensorial experiences is almost impossible, hence the passengers participate in an experience where the understanding of the physical environment remains unexpanded and the judgement of size and the dimensions of the outside space becomes impossible (Sennett, 2019, p. 178). At the same time, the lack of frontal vision in the train experience - or, more specifically, the disconnection between the frontal perception of the carriage's television screens (or passengers' screens) and the reality of the lateral views of the landscape framed by the windows - renders the immersive perception of space impossible. The outside appears to the passengers to be as flat as the screen that they have in front of them and, without the complementarity between frontal and lateral perception, the bodies of the passengers become detached from the space that they are moving through. As Sennett explains, this complementarity is essential in the distinction between place - a site in which you are or dwell - and just space, as a more generic site that you move through (Ibid., p. 185). All these perceptual phenomena are exacerbated by the increase of speed, creating a new way of viewing ("part human and part machine" as Schwarzer suggests, 2004, p. 32), where the difference in experience between travelling in the new high-speed modes and the old low-speed modes is enormous.

This feeling of obliteration of the old and the challenge represented by the new is also represented in the travellers. With the rise of the middle class in China, middle-aged Chinese people who have grown up in a completely different context (in the failures of 
modernity mentioned before) have access to the new transportation mode. The urban population in China has been growing at a rate of 20 million per year (from 1996 until now, and probably for the next 20 years), mainly nurtured by the rural exodus (Chen, 2013, p. 5); and it is these same rural people that are some of the primary users of train services in China and, progressively more, also users of the high-speed services.

This factor is also responsible for the unusual social life that can be found in the train cars, emitting a feeling of a kind of domesticity that comes from the same origin as the railways' journeys in China. In the travel book Riding the Iron Rooster, Paul Theroux writes about a passenger on a train from Harbin to Dalian in the 1980s: "few people in the train looked out of the window. They were eating noodles out of tin cups, guzzling tea, shouting or sleeping. Many were taking advantage of the recent relaxation of the rules governing card games. They were actually gambling in Hard Glass, and some groups were playing mah-jongg" (Theroux, 1988, p. 320). This familiarity is rooted in a rural way of living, where people extend their domestic customs into the public space used to a more blurred boundary between the two - and it was magisterially recorded in a series of pictures produced by the photographer Fuchun Wang from 1978 until today. In these pictures, it can be seen that families, couples and friends are acting in the public space of the train car as if it were their own home, with a total abstraction of the presence of others and the movement of the train. Observing the image, it can be argued that the rural familiarity of the train's users brings back a feeling of togetherness in the interior of the train carriage that balances the disconnection between the interior space and the outside space through which we are travelling.

Illustration 10: Sketches of the social interactions that happen in the train carriage as photographed by Fuchun Wang
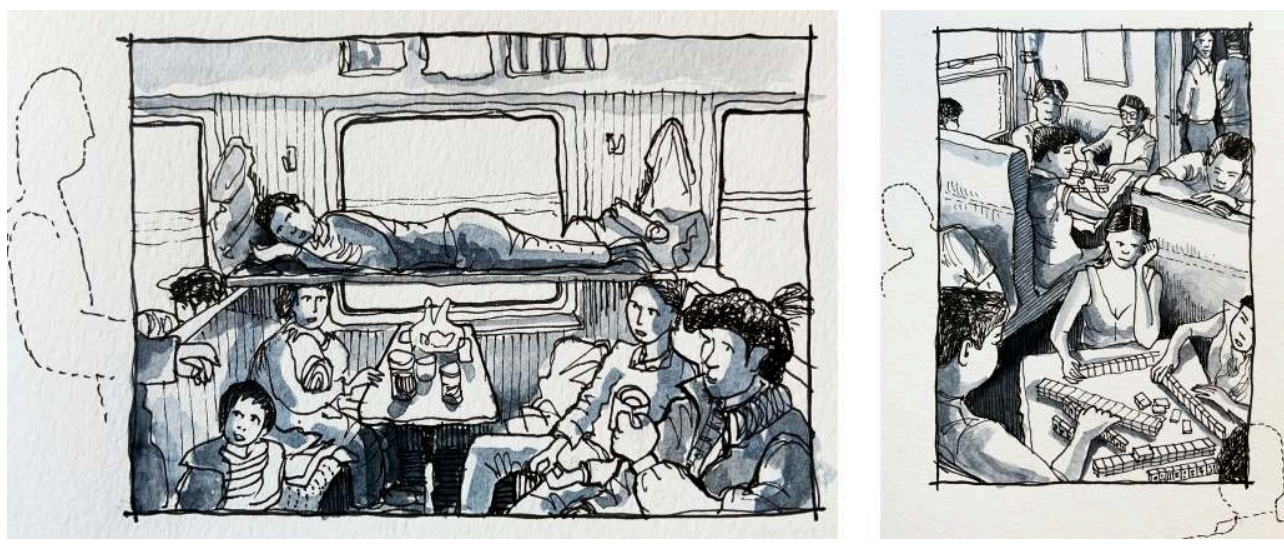

Source: Fuchung Wang's Photographs

Copyright: the authors

Answering a question about the relationship between phenomenology and real-life, art critic Hal Foster said in an interview in 2009: "phenomenology is of most interest to people when the life-world seems most mediated when almost everything seems given over to the image" (Foster, 2010, p. 137). The photographs from Wang connect the mediated world and the real world through the reflection of everyday life in the train. As Schwarzer also reminds us, "seeing the world from a train is like seeing it from a moving village" (Schwarzer, 2004, p. 47).

Scholars have compared the experience of the train journey with a moving image; as with any moving image, it is susceptible to a double-sided reading. On the one hand, as 
individual images, the train offers a patchwork of places and landscapes that are combined unpredictably with the observations of the people and events evolving in the carriages. As Mitchell Schwarzer points out, in movement, the passengers experience architecture and landscapes "within a technologically expanded visual field" that results in a perception where objects are not placed in continuous space anymore but show as "variable assemblages in intermittent space" (Ibid., p. 21). This phenomenon promotes an incohesive experience, which is a photographic reading of the journey. As Schwarzer reminds us, resuming his experience in documenting architectural landscapes from the train, the car and the aeroplane: "seen in motion, houses and whole cities roll, break apart, and recombine... Seen within frames, architecture is experienced as graphic and pictorial." (Ibid., p.12). As Paul Virilio explains, the reconfiguration of images related to the movement has a ludic component deeply connected with our childhood (1988, p. 11), and it is this reconfiguration that the train promotes through the overlapping of events that happens at different speeds in the two different worlds - the carriage and the outside. The necessity of a particular assemblage of space and events is joyful and it is complemented by a certain idea of risk from the moment at which, as Schwarzer says, we are "travelling beyond the capacities of our bodies" (2004, p. 22), in a "new way of viewing, part human and part machine" (p. 32).

On the other hand, it is inevitable that a more cohesive reading of the images should be received, in a sequence that can be termed a cinematographic reading of reality. As Patrick Keiller states in The View from the Train: Cities and Other Landscapes, "Both cinema and the railway offer more or less predetermined and repeatable spatio-temporal continuities." (Keiller, 2014, p. 160). The necessity of this continuity - as an extension of people's daily life routines - causes people to make connections between the images and frame them in a wider and more cohesive narrative. Looking to the inside, passengers are constantly receiving subtle information from visible details in order to invent narratives able to provide a cohesive understanding of what happens. Looking outside, the fragments of the landscape are also imaginatively recomposed: passengers try to permanently map their position in the territory in pursuing an understanding of where they are. As Antonio Damasio states, "the distinctive feature of brains such as the one we own is their uncanny ability to create maps... Maps are constructed when we interact with objects, such as a person, a machine, a place, from the outside of the brain towards its interior." (Damasio, 2012, p. 67). It is because of this necessity of mental mapping that the high-speed train experience becomes more problematic, provoking a series of spatial distortions that will shortly be explained, namely the "tunnel", the "one-city", the "old-but-new" and the "in-translation" effects.

The "tunnel effect", as described by Tang et al. (Tang, Savy, Doulet, 2011) is due to the fact that railway companies need to reduce the number of stops in order to retain the effectiveness of the high-speed travel, and these stops are essential for the mental mapping of the journey. With very few stations in between the lines, and with a considerable cutback in the duration of the journey, it is difficult to compose a mental map, so the passengers are in an undefined condition of in-betweenness. The passengers can place themselves in time, but cannot equally do it in space, provoking a disconnection between these two entities that challenges our rational understanding of the journey. At the same time, this fact becomes a topic for territorial controversy: some cities are in favour of the fast connections but the communities in between these 
cities suffer the inconvenience of having the rail transit going through them without receiving any benefit from it.

Equally problematic is the "one-city effect", also described by Tang et al. This effect has been created due to the new temporal proximity between some cities that has been facilitated by the new high-speed infrastructure. Some smaller cities in the proximity of big ones are now extremely well connected through the new HSR network, becoming satellite cities or remote neighbourhoods of the main city. Tianjin is a city situated 30 minutes away from Beijing, on a line intensively served from 06:15 to 22:10, and with a departure interval of 15 minutes. In a similar situation is Suzhou, less than half an hour away from Shanghai, with an equally intense connection timetable. In these cases, the megacity absorbs the workforce and talent from the smaller cities, and the smaller cities attract investment and development, creating a confusing identity between both cities and between the people, who are forced to live in a state of permanent commuting. If the tunnel effect does not allow the passengers to place themselves, this effect challenges the understanding of where the individual belongs to, therefore blurring local identities.

The "old-but-new effect" is a consequence of the urban strategy deployed through the location of the stations for the new high-speed infrastructure explained before. Used as a way to mitigate urban sprawl, and with the idea of evolving specific areas of the city through a kind of rail-oriented development, this effect is often generated when new stations are provided far away from the old ones, in totally new and underdeveloped areas of the city. In the specific case of the line between Beijing and Shanghai, only five of the 23 stations have been developed in the same location as the old ones (Ibid., p. 417). Most of the new stations were built in new areas of the cities, in places with no recognizable identity. The passengers arrive at a city where they expect to be welcomed by identifiable images of the place, but they find themselves in an unfamiliar location, sometimes desolate and poorly communicated with the older part of the city. This fact challenges the connection between space and memory, totally distorting our mental mapping of the place and leading us to feel ungrounded.

51 Finally, the "in-translation effect" is based on a new model of place created around multimodal transportation hubs. These nodes have become so intense that they are attracting the development of business centres and transportation-related industries around them, creating an identity based on people and goods constantly in translation. For instance, Shanghai Hongqiao connects a few modalities of rail transportation (HSR, intercity railway, maglev and subway) with cars, taxis, buses and trucks, which go in and out through the four highway entrances connected closely with the regional road system. All this is, at the same time, linked to national and international airlines, thanks to the Hongqiao International Airport - in this way becoming a strategic regional hub for the Yangtze River Delta area and other regions (Tang, Savy, Doulet, 2011, p. 418-419). The mapping of this place no longer responds to a feeling of belonging but instead to a fluid condition, defined by a transitory moment in the line that relates where you are coming from with where you are going next. This fluidity challenges the stability of space, which has become temporary and consequently also disputes the concepts of place and identity. In this frame, time has lost its absolute condition, becoming relative as part of a coordinated chain of events that could shift unexpectedly. This effect is the materialization of the liquid modernity (as defined by 
Bauman, 2018), resulting in unstable places with no identity, framed by an uncertain time. reframing our experience of the journey in a very particular way. These experiences cannot be understood just from the phenomenological point of view but should be viewed from a wider scope, where personal experiences are interlaced with an inevitable understanding of our context. As the theories of embodied dynamicism that arose in the 1990s state, the mind is an embodied dynamic system in the world or, in other words, the perceiver, the perception and the thing perceived are mutually codependent (Varela, Rosch, Thompson, 1992). The experience of the journey, like any other human experience, is in this way conditioned by the necessity of creating meaning (Perez Gomez, 2016, p. 144), because any phenomenological experience unavoidably provokes a symbolic interpretation. In the specific case of the experience of the journey - as a phenomenology in movement - this meaning is created in the context of an atmosphere (stimmung), as explained by Perez Gomez (p. 144), which means that whatever is experienced in the journey is connected to the movements of our body and, specifically in the case of the journey, also to our body in movement, creating an indissoluble connection between perception and emotion. It is interesting to point out here that, despite the etymological reading of "emotion" as "out of motion", movement is one of the more frequent sources of emotions because these emotions are, differently to feelings, connected to body movements (from facial to visceral), as Damasio explains (2012, p. 116-118).

Despite the previous classifications of the reading of the journey experience (referred to as photographic and cinematographic, frame and sequence, or disconnected and connected), the brain has, as Frank Wilson explains, an inscrutable way of processing both "sequential and simultaneous operations" (1999, p. 302-307) without prioritizing one specific reading. It is this complexity that makes the experience of the journey so appealing, a complexity that is exponentially increased with speed.

Illustration 11: A view of high-rise buildings under construction from the window of an HSR train in China (left); a man looking outside the window in a high-speed train in China, 2018 (right)
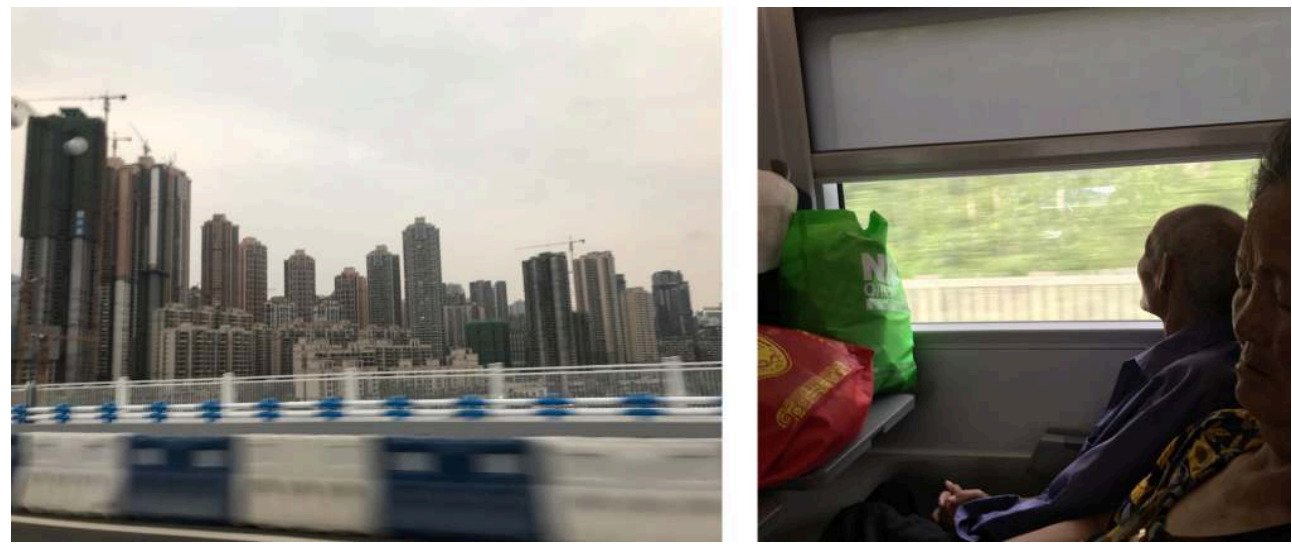

Source and Copyright: the authors 


\section{The Arrival} only extremely different (in terms of space, materiality and technology) but are also nearby each other. The situation in the Chinese stations, specifically in the new stations developed for the high-speed lines, is different for several reasons. Firstly, the proximity between the space of the platforms connected to the rail tracks and the space of the station hall connected to the city is unclear. This is because the transition to the outside is usually along a new path, disconnected from the departing space of the hall. This is due to the controlled entry, which needs a separation between in and out routes - in a similar way to what happens in an airport. The arrival is usually through an unrecognizable space that is not related to the space that has been left behind, bringing back the spatial distortions as discussed before. Secondly, differently from the Western typology of the station, the city becomes invisible from the arrival, an invisibility that is reinforced by the fact that the way out is usually tunnelled, with very few or no connections to the outside. Only after the checking-out process (again, an organized queue and the subsequent registry and control) can the passengers see their way out and get a hint of the city receiving them. The trip has concluded.

\section{Conclusions}

The authors have explored the connections between the phenomenology of the journey and the modernity approach in China, from the common ground of the "pretheoretical" situation represented by both. From the singularities in the locations of the stations to the overwhelming monumentality of the public spaces, the beginning of the train journey in China is marked by "tensions within modernity" that, in the Chinese case, are resumed in the dialectical dualities between city and countryside and among the conflict between public and private interests. The particularities of the space of the new HSR stations (its vastness and dissolution) provoke a reading of time connected to concepts like memory and expectation, also related to the understanding of Chinese modernity.

Undoubtedly, the experience of railway travel in China has changed dramatically over the last ten years, due especially to the development of the high-speed network. The development of this new infrastructure in China has occurred within the framework of a particular history, where foreign and domestic conditions greatly influenced the approach to modernity. From the colonization attempts to the failure of the Great Leap Forward and the Cultural Revolution, Chinese modernity was, in its origin, a more politically driven phenomenon in a very intense manner, dismissing the necessity of a 
more technological approach. Only after Chairman Mao's death was China able to focus on the development of the high-speed train infrastructure, but the development was affected by the peculiarities of Chinese history, influencing the phenomenology of the journey in the present day. based on historical research into understanding the conditions of the train network development before the high-speed era. This research is significant for the understanding of the peculiarities of the Chinese approach to modernity. The second line of further development of this research could be based on the detailed analysis of the particular conditions in which different high-speed train stations have been developed. Within the general framework discussed in this paper, the differences between the plan and development of the different stations would allow us a more comprehensive understanding of how the distinct conditions play in the specificities of the Chinese social and political context.

\section{BIBLIOGRAPHY}

Aldama, Zigor. 03/02/2020. La fabrica donde se construyen los misiles chinos... sobre railes, El Pais, Retina, [online]. Available online at: https://retina.elpais.com/retina/2020/01/31/ innovacion/1580469305_291157.html (consulted on April 5, 2020).

Barbara, Anna; Perliss, Anthony. 2006. Invisible Architecture: Experiencing Places through the Sense of Smell. Milano: Skira.

Bauman, Zygmunt. 2018. Liquid Modernity. Cambridge: Polity Press.

Beaumont, Matthew \& Freeman, Michael J. 2007. The Railway and Modernity: Time, Space, and the Machine Ensemble. Bern: P. Lang.

Chen, Chia-Lin \& Wei, Biao. 2013. High-Speed and Urban Transformation in China: The Case of Hangzhou East Rail Station. Built Environment, vol 39, no. 3, p. 385-398.

Chen, Zhen. 2013. Railway station and urban transition in China. Planum, The Journal of Urbanism, n. 27, vol. 2 [online]. Available online at: http://www.planum.bedita.net/download/ _nul_conference_proceedings-chen_session_2-pdf (consulted on April 5, 2020).

Daly, Nicholas. 1999. Railway Novels: Sensation Fiction and the Modernization of the Senses. ELH BALTIMORE- vol 66, no. 2: p. 461-488.

Damasio, Antonio. 2012. Self Comes to Mind. Constructing the Conscious Brain. New York: Vintage Books.

Dostal, Robert J. 1993. Time and phenomenology in Husserl and Heidegger. In: Guignon, Charles B. (eds.). The Cambridge Companion to Heidegger. Cambridge: Cambridge University Press, p. 141169.

Ford, Larry R. 2008. World Cities and Global Change: Observations on Monumentality in Urban Design. Eurasian Geography and Economics, vol 49, no. 3: p. 237-262. 
Foster, Hal. 2010. New Monumentality: Architecture and Public Space. Perspecta, vol 42, p. 135-139.

Foucault, Michel. 1991. Discipline and Punish: The Birth of the Prison. Translated by A. Sheridan, London. New York: Penguin.

Gibson, James Jerome. 1997. The perception of the visual world. Westport: Greenwood Press.

Giedion, Sigfried, Sert, Jose Luis, \& Léger, Fernand. 1943. Nine Points on Monumentality. In: Giedion, S., Architecture, You and Me, Diary of a Development. Cambridge: Harvard University Press. p. 48-51.

Haixiao, Pan \& Ya, Gao. 2019. Development of High-Speed Rail in the People's Republic of China. ADBI Working Paper 959. Tokyo: Asian Development Bank Institute. Available on line at: https:// www.adb.org/publications/development-high-speed-rail-prc (consulted on April 5, 2020).

Hornsby, Adrian. 2009. Tiananmen Square: the history of the world's largest paved square. The Architectural Review, [online]. Available online at: https://www.architectural-review.com/essays/ tiananmen-square-the-history-of-the-worlds-largest-paved-square/8691533.article (consulted on April 5, 2020).

Huang, Yaping; Lu, Shiwei; Yang, Yiping and Zhao, Zhiyuan. 2018. Exploring Railway Network Dynamics in China from 2008 to 2017. International Journal of Geo-Information, vol 7, no. 320 [online]. Available on line at: https://www.researchgate.net/publication/ 326917113_Exploring_Railway_Network_Dynamics_in_China_from_2008_to_2017 (consulted on April 5, 2020).

Husserl, Edmund, \& Brough, John Barnett. 2011. On the phenomenology of the consciousness of internal time (1893-1917). Dordrecht: Kluwer Academic Publ.

Jian, Zhen (Ed.), 2019. A study of the 13th Five-Year Plan for the development and planning of railway road. Beijing: China Railway Publishing House [original in Chinese].

Keiller, Patrick. 2014. The View from the Train: Cities and Other Landscapes. London: Verso.

Klein, Thoralf. 2014. How Modern was Chinese Modernity? Exploring Tensions of a Contested Master Narrative. International Journal for History, Culture and Modernity, HCM, vol 2, no. 3: p. 275301.

Köll, Elisabeth. 2019. Railroads and the Transformation of China. Cambridge: Harvard University Press.

Lin, George C. S. 1997. Red Capitalism in South China: Growth and Development of the Pearl River Delta. Vancouver: University of British Columbia Press.

Lucae, Richard. 1869. Uber Die Macht Des Raumes in Der Baukunst. Zeitschrift für Bauwesen, no. 19, p. 294-306.

Mildenberg, Ariane. 2017. Modernism and Phenomenology: Literature, Philosophy, Art. London: Palgrave Macmillan.

Parks, Tim. 2014. Italian Ways: On and Off the Rails from Milan to Palermo. London: Vintage.

Pérez Gómez, Alberto. 2016. Attunement: architectural meaning after the crisis of modern science. Cambridge: The MIT Press.

Proust, Marcel. 1981. Remembrance of Things Past, New York: Random House. 
Quian, Zhu. 2014. China's pre-reform urban transformation: the case of Hangzhou during the Cultural Revolution (1966-1976). International Development Planning Review, vol 36, no. 2, p. 181203.

Rowe, Peter G., \& Kuan, Seng. 2002. Architectural Encounters with Essence and Form in Modern China. Cambridge: The MIT Press.

Schivelbusch, Wolfgang. 1977. The Railway Journey: The Industrialization of Time and Space in the Nineteenth Century. New York: Urizen Books.

Schwarzer, Mitchell. 2004. Zoomscape: Architecture in Motion and Media. New York: Princeton University Press.

Sennett, Richard. 2019. Building and dwelling: ethics for the city. London: Penguin Books.

Smith, Christopher J. 2008. Monumentality in Urban Design: The Case of China. Eurasian Geography and Economics, vol 49, no. 3, p. 263-279.

Tang, Frank. 03/01/2019. Full Speed Ahead for China's High-Speed Rail Network in 2019 in Bid to Boost Slowing Economy. South China Morning Post, [online]. Available on line at: https:// www.scmp.com/economy/china-economy/article/2180562/full-speed-ahead-chinas-high-speedrail-network-2019-bid-boost (consulted on April 5, 2020).

Tang, Shuangshuang; Savy, Michel; \& Doulet, Jean-Francois. 2011. High speed rail in China and its potential impacts on urban and regional development. Local Economy, vol 26, no 5, p. 409-422.

Available online at: https://www.researchgate.net/publication/

227574865_High_Speed_Rail_in_China_and_its_Potential_Impacts_on_Urban_and_Regional_Development (consulted on April 5, 2020).

Theroux, Paul. 1988. Riding the Iron Rooster. New York: Ivy Books.

Varela, Francisco J.; Rosch, Eleanor \& Thompson, Evan. 1992. The Embodied Mind: Cognitive Science and Human Experience. Cambridge, Massachusetts: MIT Press.

Virilio, Paul. 1988. Estética de la Desaparición. Barcelona: Anagrama.

Wang, Xiong. 2016. China Speed: Development of China's High-Speed Rail. Beijing: Foreign Languages Press.

Wilson, Frank. 1999. The Hand: how its use shapes the brain, language, and human culture. New York: Vintage.

Zhu, Jianfei. 2009. Architecture of Modern China. A historical critique. London: Routledge.

\section{ABSTRACTS}

Hosting more than two-thirds of the global high-speed train network, and growing at an unprecedented rate, China has become an interesting location for studying this infrastructure. In this paper, the authors begin by introducing some particularities related to the high-speed travel experience, in order to provide a general understanding of how it affects people's perceptions of time and space. This is followed by an explanation of some peculiarities that have defined the Chinese case as unique. Grounded on theories that assert the interlaced connection between modernity and phenomenology, in this paper the authors explore the connection between the conditions that defined modernity in China and the phenomenology of travel using high-speed trains. The problematic initial approach to Chinese modernity - through the Great Leap Forward and the Cultural Revolution - impacted later decisions regarding the new infrastructure, rendering high-speed train journeys in China unique. After the end of the Cultural Revolution in 
1976, when China recovered a sense of normality and togetherness, modernity was globally staged out. Two years later, China commenced the development of its high-speed rail (HSR) network and the beginning of the reform era, as part of its statements of a reframed modernity. This paper explores how the singularities of the Chinese modernity have affected the development of the High-speed train network, defining a particular phenomenology of the trip.

Accueillant plus de deux tiers du réseau mondial de trains à grande vitesse et enregistrant une croissance inédite, la Chine est devenue une zone d'intérêt pour étudier son infrastructure. Dans cet article, les auteurs présenteront tout d'abord certaines spécificités liées à l'expérience du voyage à grande vitesse afin de fournir une vision d'ensemble de la façon dont les perceptions du temps et de l'espace sont influencées. Ensuite, ils expliqueront les éléments qui font de la Chine un cas unique. Se basant sur des théories qui soutiennent le lien entre modernité et phénoménologie, les auteurs explorent dans cet article la relation entre les conditions qui ont défini la modernité en Chine et la phénoménologie du voyage à bord de trains à grande vitesse. L'approche initiale problématique relative à la modernité chinoise, avec le Grand Bond en avant et la Révolution culturelle, a influencé les décisions ultérieures en termes de nouvelles infrastructures, faisant des trajets en trains à grande vitesse en Chine une expérience unique. À la fin de la Révolution culturelle en 1976, la Chine avait retrouvé une sorte de normalité et d'unité, et la mordernité recula de façon générale. Deux ans plus tard, la Chine commença le développement de son réseau de lignes à grande vitesse (LGV). C'est le début d'une ère de réformes, participant aux annonces d'une modernité redéfinie. Cet article explore la façon dont les singularités de la modernité chinoise ont influencé le développement du réseau de train à grande vitesse, définissant ainsi une phénoménologie particulière du voyage.

\section{INDEX}

Keywords: China, high-speed train network, modernity, phenomenology

Mots-clés: Chine, réseau de trains à grande vitesse, modernité, phénoménologie

\section{AUTHORS}

\section{JUNJIE XI}

Junjie Xi is a lecturer in architectural design and humanities at the University of Liverpool. She worked as a Postdoctoral researcher for the China Railway Group Limited and School of Architecture, Tsinghua University from 2016 to 2018. Her project "The Use of Flexible Architecture and Structures in the Design of Public Buildings" was funded by China Railway and the research outputs will be used by this state-owned enterprise in their construction work in the future. She published her book Small-Scale Public Transportable and Pre-Fabricated Buildings: Evaluating their Functional Performance in March 2018. She is currently writing a new book China's High-Speed Railway Transformation: Infrastructure Investment and Urban Development.

\section{PACO MEJIAS VILLATORO}

Paco Mejias Villatoro is a registered architect in Spain and the UK, and he holds a PhD in Architectural Theory and Design from the Madrid Polytechnic University. He has been teaching Architecture since 1997, in Spain, Canada, the United States and China. As a practitioner, he worked for Zaha Hadid Office in London, before opening his firm in Spain. He has been awarded in several competitions and nominated for the prestigious Mies van der Rohe Prize. He is 
nowadays co-director of Estudio Abierto/Open Studio, a collaborative think-and-do tank, operating at the intersection between architecture and urbanism (https://

www.thisstudioisopen.org/). 